Ana Dili Eğitimi Dergisi
Journal of Mother Tongue Education
ADED - JOMTE
www.anadiliegitimi.com

\title{
Türkçe Ders Kitaplarında (6-8. Sınıflar) Yer Alan Okuma Kültürü Teması Metinlerinin
}

\author{
Mehmet Akif ÇEÇEN* \\ Bahar DOĞAN** \\ Özet
}

Metinler Arasılık Bakımından İncelenmesi

\begin{abstract}
Bu araştırmada ortaokul Türkçe ders kitaplarındaki metinlerin metinler arasılık bakımından incelemesi yapılmıştır. Araştırmada, Milî Eğitim Bakanlı̆̆ tarafından 2011-2012 öğretim yılında okutulan ortaokul Türkçe ders kitaplarında okuma kültürü temasını içerenler arasından ulaşılabilen üç kitapta bulunan on altı metin, metinler arasılık ölçütüne göre incelenmiştir. Metinlerin incelenmesinde betimsel analiz kullanılmıştır. Metinler arası ilişkileri sağlayan "yazarlar arası, eserler arası, türler arası, açık ve örtük göndermeler" bakımından incelenen on altı metinden dördünde (Kütüphane, Kitap Saygısı, Rejin Hanım ve İmza Günü ) hiçbir metinler arası söyleme rastlanmamıştır. Geriye kalan on iki metinde ise en fazla metinler arası söylem "Kitaplarda Gezmek", "Sait Faik Adasında" ve "Çocuk Kitaplığında Sabah Tartışması" metinlerinde tespit edilmiştir. Çalışmanın sonunda ders kitapları için metin seçilirken metinler arası anlam kurmayı sağlayabilecek metinlere yer verilmesi önerilmiştir.
\end{abstract}

Anahtar Kelimeler: Metinler arasılık, okuma kültürü, Türkçe ders kitabı

\section{Examining Reading Culture-Themed Texts In Turkish Textbooks of Elemantary School In Terms of Intertextuality}

\begin{abstract}
In this study, texts in Turkish textbooks of elementary school was aimed to be examined in terms of intertextuality. In the study, sixteen texts which containing theme of reading culture in textbooks recommended by the Ministry of National Education in academic year of 2011-2012 in Turkey and the three books could reached by researcher were examined according to the criteria of intertextuality. Descriptive analysis was used for examining the texts. Intertextual expression has not been observed four of six from the text on them (Kütüphane, Kitap Saygısı, Rejin Hanım ve İmza Günü) providing intertextual relations that were examined in terms of "inter-authors, inter-literal works, inter-genre, references to explicit and implicit" The remaining twelve in the texts maximum of intertextual discourse have been determined in "Kitaplarda Gezmek", "Sait Faik Adasında" and "Çocuk Kitaplığında Sabah Tartışması" texts. When selecting text for textbooks, it is necessary to use texts which help establishing intertextual meaning.
\end{abstract}

Keywords: Intertextuality, reading culture, the Turkish language textbooks

\footnotetext{
* Doç. Dr., İnönü Üniversitesi, Eğitim Fakültesi, Türkçe Eğitimi Bölümü, Malatya. E-posta: mehmet.cecen@inonu.edu.tr

${ }^{* *}$ Arş. Gör. ., İnönü Üniversitesi, Eğitim Fakültesi, Türkçe Eğitimi Bölümü, Malatya. E-posta:

bahar.dogan@inonu.edu.tr
} 


\section{Okuma Kültürü Teması Metinlerinin Metinler Arasılık Bakımından İncelenmesi}

\section{Giriş}

Türkçe öğretiminde metinler, önemli araçlardır. Metne dayalı dil öğretiminde bir metnin diğer metinlerle ilişkili olarak okunması, sorgulama; eleştirel, analitik düşünme gibi üst düzey düşünme becerilerini kullanmayı gerektirir. Bu nedenle Türkçe öğretiminde metinler arası okuma da önemli bir yere sahiptir.

Metinler arası okuma kavramı resmî olarak ilk kez 2004-2005 eğitim-öğretim yılında değişen İlköğretim Türkçe Dersi Öğretim Programı ve Kılavuzu'nda (1-5. Sınıflar) yer almıştır. Programın özellikleri belirtilirken metinler arası okumanın temel beceriler arasında yer aldığı belirtilmiştir:

"Türkçeyi doğru, etkili ve güzel kullanma, eleştirel düşünme, yaratıcı düşünme, iletişim, problem çözme, araştırma, bilgi teknolojilerini kullanma, girişimcilik, karar verme, metinler arası okuma, kişisel ve sosyal değerlere önem verme gibi temel becerilere yer verilmiştir." (MEB, 2009: 11).

Ayrıca programda "anlama becerilerinin geliştirilmesi amacıyla sıralama, sınıflama, eleştirme, tahmin etme, ilişki kurma, özetleme, analiz-sentez yapma ve değerlendirme gibi etkinlikler verilmiş; metin içi, metin dışı ve metinler arası okuma yoluyla anlam kurmaya özen gösterilmiştir" (MEB, 2009: 11).

Programın genel amaçlarında da öğrencilerin, metinler arası okuma becerilerini geliştirerek söz varlıklarını geliştirebilecekleri belirtilmiş ve program sözlüğünde metinler arası anlam kurma, "bir konu ile ilgili farklı metinlerden (örneğin kitap, dergi, gazete vb.) alınan bilgilere dayalı yeni anlam oluşturma" olarak tanımlanmıştır (MEB, 2009: 407).

Benzer ifadeler söz konusu programın dördüncü ve beşinci sınıf okuma alanlarında anlam kurma amacı altında "Metinler arası anlam kurar." kazanımı ile de yer almaktadır. Ayrıca bu kazanım “En az iki kaynaktan edindiği bilgileri kullanarak yeniden anlam kurma” şeklinde açıklanmıştır (MEB, 2009: 86; 108).

Illköğretim Türkçe Dersi Öğretim Programı ve Kılavuzu'nda (1-5. Sınıflar) sıklıkla söz edilen ve önemi vurgulanan metinler arası okuma ifadesine İlköğretim Türkçe Dersi Öğretim Programı́nda (6-8. Sınıflar) sadece okuma türlerinden metinlerle ilişkilendirerek okuma (MEB, 2009: 69) örneğinde rastlanmıştır.

Metinler arası ya da metinler arasılık (intertextuality) kavramının ne ifade ettiği, ilk olarak ne zaman kullanıldığı ve belirli şair ve yazarların eserlerindeki metinler arası ilişkiler üzerine birçok çalışma yapılmıştır.

Metinler arası okuma, ülkemiz açısından okuma ve öğretimi alanında yeni sayılabilecek bir kavramdır (Akyol, 2010: 232). Batı'da ilk olarak Julia Kristeva, 1960'ların sonlarında Saussurean ve 
Bakhtinian'ın teorilerinden yola çıkarak metinler arası teorisini dil ve edebiyat için öne sürmüştür (Allen, 2000).

Işıksalan (2007), bir kültür ortamında doğan metnin, kendinden önceki metinlerin evreninde dolaştığı gibi kendisinden sonraki metinler için de kısmen ya da tamamen bir malzeme olabileceğini ve örtülü veya açık göndermelerle metinler arasında yakınlık, benzerlik, karşıtlık, öykünme biçiminde değişik biçim ve boyutlarda ilişkinin kurulmasına aracılık edeceğini belirtir.

Akyol (2010) da metinler arası okumanın, okuma alanına metin kavramını bugüne kadar düşünülenden daha geniş bir çerçeve içerisinde ele alması ve sorulara verilen cevapların kaynağının belirlenmesi bakımından katkıda bulunduğunu belirtir. Ayrıca "metinler arası okumanın özünün, metinlerdeki düşünceler ve fikirler arasında ilişkiler kurarak yeni manalar üretmek" (Akyol, 2010: 233) olduğundan söz eder.

“Metinler arasılık çalışması, metinler arasındaki ilişkilerin belirli türlerinin bir araştırmasıdır. Bir metin diğer, başka metinlerden alıntılar yapabilir. Alıntı burada tercihen daha yaygın referanslar, göndermeler, tekrarlar, hatırlatmalar ya da dönüşümler genel olarak da fenomenleri tanımlama yolları olarak seçilebilir" (Edmunds, 2001: 134).

"Yazı içinde önceki metinlerden izler taşır. Böylece metinler arası, sonsuz bir metin alanını kapsar. Kristeva metni, daha önce yazılmış ya da çağdaş metinlerle ilişki içine sokarak bir yandan kendi iç dizgesi içerisinde çözümler ve onunla daha önce yazılmış metin dizgeleri arasındaki ilişkiyi saptamaya çalışır. Kısaca söylemek gerekirse Kristeva, metinden ve metinler arasılık tanımından her türlü insan izini silerek, onu yalnızca bir dil olgusu çerçevesinde tanımlar. Kristeva'da özneler arasılık kavramının yerini metinler arasılık alır" (Rızvanoğlu, 2007: 6).

Aktulum (2000), metinler arasılığın bir yeniden yazma işlemi olduğunu ve bir yazarın bir başka metni kendi metninin bağlamında yeniden oluşturduğunu ve bu dönüşümün alıntı, anıştırma, çalıntı, öykünme-pastiş, parodi, alaycı dönüştürüm, tarzında açık ya da kapalı göndermeler vasıtasıyla gerçekleştiğini belirtir.

Günay (2007: 211) ise Aktulum'un sözlerini destekler nitelikte bir metnin diğer tüm alıntılardan yalıtılmış, onlardan soyutlanmış bir şey olmadığını belirtir ve "bir metin tek başına yazılmamıştır, tek başına değildir ve tek başına okunamaz. Metinler arasılık kavramı, bir metin ya da metinler grubunun başka metinlerle olan açık ya da gizli ilişkilerini belirtir" der.

Bu doğrultuda metinler arasılık, "bir metin arasındaki diğer metinlerdir" (Plett, 1991) denilebilir. 


\section{Okuma Kültürü Teması Metinlerinin Metinler Arasılık Bakımından İncelenmesi}

Toklu ise metinler arasılığı "metinler arasındaki ilişkiler yapısı ve metinlere ilişkin bilgilerin kullanımları sırasında etkinleşmesi" olarak tanımlar (2009: 134).

Coşkun Ögeyik (2008), metinler arasılık betimlemesini beş ana başık altında sınıflandırmıştır: Yazarlar arası, eserler arası, türler arası, açık ve örtük göndermeler. Araştırmanın yönteminde belirtildiği üzere söz konusu metinler bu sınıflandırmaya göre analiz edildiği için yazarın çalışmasından yararlanılarak bu göndermeler ile ilgili kısa bilgilerin verilmesi uygun görülmüştür.

"Yazarlar arası göndermeler: Metinler arasılık, yazarlar arası gönderimde hem bir başka yazarın söylem özelliğine, hem kendisine, hem de biçemine gönderme olabilir. Bu tür söylemler bir öykü türünün başka öykülerle olan bağıntısını gösterir ve o öykünün türünü belirler; bu durumda o öykü okurunun öykü karşısında belli bir tutum almasını gerektirerek güçlü bir metinlerarası işlev görür. Eserler arası göndermeler: Bir başka esere atıf, bir eserin yeniden yazılması, bazı eserlerin esere konu edilmesi biçiminde olabilir. Türler arası göndermeler: Bazı yazınsal metinlerde, metinler arasııık, başka yazın türlerinden ya da metin türlerinden alınan alıntılarla oluşturulur. Açık göndermeler: Bazı metinlerde metinler arasılık olduğu açıkça kaleme alınır ve ilgili metinden bir alıntı metne yerleştirilir. Örtük göndermeler: Aynı yazarın veya şairin farklı eserlerine gönderimler olabilir ya da başka yazarların ve şairlerin eserlerine örtük biçimde yapılan gönderimler olabilir" (Coşkun Ögeyik 2008: 50-77).

Yukarıda yer alan tanımların ortak noktası, her metnin belirli özellikler açısından birbirinden izler taşıdığı, bu izlerin bazen doğrudan alıntılamalar yoluyla bazen ise yazarlar arası göndermelerle yapıldığı üzerinedir. Metinler arasılık ile ilgili çalışmalar genellikle bir yazarın eserleri üzerine metinler arasılık (Akbulut, 2009; Gökalp Alpaslan, 2009; Bars, 2013) ya da iki eser arasındaki metinler arası okuma (Tunç, 2009; Bayrak Akyıldız, 2010; Qasımova, 2011) ile ilgilidir.

Illköğretim Türkçe Dersi Öğretim Programı ve Kılavuzu'nda (1-5. Sınıflar) temel beceriler arasında yer alan metinler arası okuma, Akyol'a (2010: 234) göre metinler arası düşünme ve alternatif bakış açıları geliştirmeye yol açacaktır. Bir toplumdaki demokratik, hukuksal, ahlakî, kültürel vb. değerler metinler arası anlayışın hâkim olduğu düşünce sisteminde hem daha anlaşılır şekilde ifade edilecek hem de toplumun bireyleri tarafından daha fazla kabul görecektir. Bireyin özgürlüğünün sınırları da başkalarını rahatsız etmeden genişleyecektir.

Bu derece önem arz eden metinler arası okumaya programın uygulama sahası sayılan ve Türkçe öğretiminde önemli bir araç olan ders kitaplarında ne derece yer verildiği araştırma kapsamında incelenmek istenmiştir. Çünkü Özbay'ın (2003: 27) belirttiği üzere öğretmenlerin derslerinde kullandıkları öğretim materyalleri arasında, Türkçe ders kitapları \%94,44 gibi bir oranla ilk sırayı almaktadır. 
Alanyazında ders kitaplarında metinler arası okuma bakımından ulaşabilen bir çalışma bulunmaktadır. Karatay (2010), öğrenme sürecinde öğrenciyi etkin kılan ve yapılandırmacı öğrenme kuramı anlayışı ile hazırlanan Türkçe dersi kitabı ve öğretmen kılavuzunu, metinler arasılık ölçütü bakımından değerlendirmiştir. Üç farklı sınıf ve yayınevine ait Türkçe dersi kitabı ve öğretmen kılavuzu metinler arasılık ölçütü bakımından incelemiştir. Öğretim araçlarında öğrenmeyi yapılandırmak için işlenen tema ve metinlerdeki göndermelerin, Türkçe dersi dışındaki disiplinlerle ilişkilendirme şeklinde yapıldığını ve bunların da her tema ve metinde yeteri kadar sağlanamadığını tespit etmiştir.

Alanyazında okuma kültürü temasında yer alan metinlerin metinler arasılığı üzerine çok fazla çalışma yapılmadığı için bu araştırmada ortaokul ders kitaplarındaki okuma kültürü temalı metinlerin metinler arasılık bakımından incelenmesi amaçlanmaktadır.

\section{Yöntem}

\section{Çalışma Materyali}

Araştırmada, Millî Eğitim Bakanlığı tarafından 2011-2012 öğretim yılında okutulan ders kitapları içerisinde okuma kültürü temasına yer verilen ve araştırmacının ulaşabildiği üç kitapta bulunan on altı metin, metinler arasılık ölçütüne göre incelenmiştir. Araştırmada okuma kültürü temalı metinlerin seçilme nedeni farklı yayınevlerinin, kitaplarında ortak tema olarak bu temaya yer vermiş olmalarıdır. Çalışma materyaline ilişkin bilgiler şöyledir:

Tablo 1. Çalışma materyaline ilişkin bilgiler

\begin{tabular}{lll}
\hline \multirow{2}{*}{ Yayınevi } & Metnin adı & Yazarı \\
\hline MEB & Kütüphane & M. Nihat MALKOÇ \\
& Çocuk Kitaplığında Sabah Tartışması & Mehmet GÜLER \\
& Canım Kitap & Suut Kemal YETKIN \\
& Kitap & Muzaffer HACıHASANOĞLU \\
& Vitrindeki Masal Kitabı & Üzeyir GÜNDÜZ \\
Pasifik & Kitaplarda Gezmek & Adalet AĞAOĞLU \\
& Kitaplar Arasında & M. MARK ve N. MCQUEEN \\
& Kitap ve Gelişen Teknoloji & Sevinç SAKMAN \\
& Kitabın Serüveni & Mustafa Necati ÖNGAY \\
& Rejin Hanım & Çetin ALTAN \\
& İmza Günü & Mehmet GÜLER \\
Koza & Keloğlan & Mehmet BAŞARAN \\
& Sonsuzluk Kitabevi & Sabahattin Kudret AKSAL \\
& Kitap Saygısı & Rauf MUTLUAY \\
& Okumak & Hasan Âli YÜCEL \\
& Sait Faik Adasında & Mehmet GÜLER \\
\hline
\end{tabular}

\section{İşlem ve Verilerin Analizi}

Coşkun Ögeyik'in (2008) çalışmasından hareketle araştırmada, okuma kültürü temasında yer alan toplam on altı metinde metinler arası ilişkileri sağlayan "yazarlar arası, eserler arası, türler arası, açık ve örtük göndermeler" ayrı ayrı analiz edilmiş ve elde edilen bulgular, tartışma bölümünde değerlendirilmiştir. 


\section{Okuma Kültürü Teması Metinlerinin Metinler Arasılık Bakımından İncelenmesi}

Metinlerin incelenmesinde betimsel analiz kullanılmıştır. "Betimsel analiz"de elde edilen veriler, daha önceden belirlenen temalara göre özetlenir ve yorumlanır. Bu tür analizde amaç, elde edilen bulguları düzenlenmiş ve yorumlanmış bir biçimde okuyucuya sunmaktır. Bu amaçla elde edilen veriler, önce sistematik ve açık bir biçimde betimlenir. Daha sonra yapılan bu betimlemeler açıklanır ve yorumlanır, neden-sonuç ilişkileri irdelenir ve birtakım sonuçlara ulaşılır (Yıldırım ve şimşek, 2005: 224).

\section{Bulgular}

\section{Yazarlar Arası Göndermeler}

"Kitaplar Arasında" metni ile "Çocuk Kitaplığında Sabah Tartışması" metni arasında yazarların söylem özelliklerinin benzerliği dolayısıyla yazarlar arası gönderme yapııdığı söylenebilir. Çünkü her iki metinde de yazarlar, kitaplar konuşturulmuş ve metnin temasına uygun ifadeler bu üslupla okuyucuya aktarılmak istenmiştir.

"Sonsuzluk Kitabevi" adlı metinde birçok ünlü simaya gönderme yapılmıştır: Metinde yazar, Platon, Sokrates, Aristoteles, Epiktetos, Herakleitos, Horatius, Ovidius, Vergilius, Seneca, Petrarca, Rabelais, Cervantes, Gothe, Rimboud ve Çehov'dan söz etmiştir (Sonsuzluk Kitabevi-Sabahattin Kudret Aksal).

"Okumak" metninde de yazar, Sokrat ve Platon'dan söz etmiştir (Okumak- Hasan Âli Yücel).

"Okumak" metni için hem "Canım Kitap" hem de "Kitaplarda Gezmek" metinleri ile yazarlarının üsluplarının benzerliği dolayısıyla metinler arası bir ilişki olduğu belirtilebilir.

"Okumak" metninde Hasan Âli Yücel kitaplarla ilgili düşüncelerini şu şekilde dile getirmektedir:

“Bir an kendini tek başınıza bir odaya kapatılmış olarak düşünün. Biraz ekmek ve su bulduktan sonra ilk arayacağınız şey dilinizden anlayan konuşacak bir insandır, değil mi? Bu his, içinde yaşadığınız cemiyetten uzak kalmanın verdiği manevi açlığınızın giderilmesini istemekten başka insanlarla olan bağınızın koparılması kaygısından başka ne ifade eder?

Yalnızlıkta dost ve arkadaş yokluğunun yerini ancak kitap tutabilir. Bulabildiğiniz kitabı yazan, sizin bu tek başına kaldığınız anda konuşabileceğiniz tek arkadaş değil midir?

Yazık okumaya alışmamış, onun tadını almamış olanlara. Onlar, ıssız bir âlemde, yapayalnız yaşamaya mahkûmdurlar."

"Canım Kitap" metninde ise Suut Kemal Yetkin, Yücel’e yakın söylemlerle kitaplar hakkındaki düşüncelerini dile getirmiştir: 
"Dünyada hiçbir dost, insana kitaptan daha yakın değildir. Sıkıntımızı unutmak, donuk hayatımıza biraz renk katmak, biraz ışık vermek, daracık dünyamızda bulamadığımız şeyleri yaşamak için tek çaremiz kitaplara sarılmaktır... Herhangi bir yolculuğa çıkarken hangi okuryazar yanına bir iki roman, bir iki şiir kitabı almayı düşünmez. Yolculukta, çoğu zaman olduğu gibi çevremize bakıp dalmaktan yanımıza aldığımız kitapları okuyamazsak bile onları yine de elimiz altında bulundurmak isteriz. Çünkü onların can yoldaşı olduğunu biliriz."

Hasan Âli Yücel, "Okumak" metninde okuma ile ilgili şu düşüncelere yer vermiştir:

“Onun içindir ki yazı, birçok olamamazlıkları olur yapmıştır. Ölü dirilmez, yüz kuruşa Amerika’ya gidilmez, her büyük adam bizimle konuşmaz. Bu böyledir de en büyük yazıcıların herhangi bir kitabını pek güzel yüz kuruşa alır ve bu büyük düşünücü ile baş başa on gün, yirmi gün, bir ay oturup konuşabilirsin."

Yücel'in söylemlerinin benzerine Adalet Ağaoğlu'nun üslubu ile "Kitaplarda Gezmek" metninde de rastlanır:

"Birçok kimsenin yaz tatilinde bir yerlere gitmeye hazırlandığı, yepyeni coğrafyalarda olmayı tasarladığı fakat ekonomik nedenlerle çoğunluğunun bunu düşünmekte bile güçlük çektiği şu günlerde, biraz da kitaplardan, kitaplarla yapabileceğimiz yolculuklardan söz açmak istiyorum. Ne de olsa her biri beş on bin lira içinde yapılabilecek geziler bunlar..."

\section{Eserler Arası Göndermeler}

"Kitaplarda Gezmek" metninde Adalet Ağaoğlu, bir başka esere atıf yapma yoluyla eserler arası göndermeyi oldukça fazla kullanmıştır. Metinde sözü edilen Seyahatnâme, Gece Uçuşu, L'Education Sentimentale, Venedik'te Ölüm, Memleketimden Insan Manzaraları, Beş Şehir gibi eserler bu duruma örnek gösterilebilir:

“Evliya Çelebi'nin setresi ucuna tutunup Seyahatnâme ile Osmanlı topraklarını arşınlayanlarımız, bir günün içinde kendini Bursa dolaylarından Karadeniz kıyılarına atanlarımız az değildir."

"Sonraları, Exupéry'nin yanına kurulup bir Gece Uçuşu yaptığımız da olmuştur."

"Daha şık, daha iç açıcı yerler mi istiyorsunuz? Hem de coğrafyanın içinde geniş parklar, büyük tarihî yapılar, süslü kadınlar mı olsun? Gönül ki Yetişmekte'nin (L'Education Sentimentale) sayfalarında Flaubert size bol bol sunacaktır bunları."

“Haftaya Venedik'te Ölüm'ü birlikte dolaşalım mı?” 


\section{Okuma Kültürü Teması Metinlerinin Metinler Arasılık Bakımından İncelenmesi}

“Nazım Hikmet'in Memleketimden Insan Manzaraları'nı ilk gençliğimde okumuş, ülkenin çeşit çeşit insanlarıyla ilkin Haydarpaşa Garı'nda tanışmıştım. Tanpınar'ın Beş Şehir'i, bu kentlerin birbirini bile görmediğimiz zamanlarda, teker teker belleğimize kazınmamış mıdır?”

Yazar, söz konusu metinde eserler arası göndermeler yaparken aynı zamanda atıf yapılan eserlerin kimlere ait olduğunu da belirttiği için yazarlar arası gönderme de yapmış olmaktadır.

"Kitap ve Gelişen Teknoloji" metninde, gelişen teknolojiye rağmen kitap okuman önemi anlatıırken Çalıkuşu ve Cimri adlı eserlere gönderme yapılmıştır:

“Hangi elektronik ağ sitesi Çalıkuşu'nun Feride'sini Reşat Nuri Gültekin'in satırlarındaki canlılıkla bizim dünyamıza taşıyabilir. Hangi bilgisayar mesajı ile Molier'in Cimri'sindeki Harpagon karakterini tanıyabiliriz."

"Çocuk Kitaplığında Sabah Tartışması" adlı metinde bazı eserler metne konu edilerek hatta o eserlerin kahramanları konuşturularak eserler arası göndermede bulunulmuştur. Metinde Don Kişot, Walt Disney, Güliver'in Gezileri, Küçük Prens, La Fontaine Masalları, Nasrettin Hoca Fıkraları, Andersen Masalları'na göndermeler yapılmıştır.

"Vitrindeki Masal Kitabı" metninde 'Binbir Gece Masalları'na atıfta bulunulmuştur. Ancak yazarın burada bahsettiği eserin bilinen Binbir Gece Masalları'ndan farklı olduğu söylenebilir. Çünkü yazarın belirttiği eserde Keloğlan, Alaaddin'in Lambası gibi masallar yer almaktadır.

"Sait Faik Adasında" adı metinde Mehmet Güler, Sait Faik Hikâyeleri'ne gönderme yapmıştır: “Haritada Bir Nokta, Bizim Köy Bir Balıkçı Köyüdür. Projektörcü, Papaz Efendi, Son Kuşlar ve Hişt Hişt metinde yer alan hikâyelerdir.

\section{Türler Arası Göndermeler}

"Keloğlan" başlıklı metinde Mehmet Başaran, masal kahramanı Keloğlan'ı ve maceralarını şiir türünde anlatmaya çalışmış ve bu şekilde türler arası gönderme yapmıştır:

“Keloğlan kel ama akıllı çocuktur/Aklı taş çıkartır müneccimlere ...

Bakarız dünyanın durumu kötü ... / Zalim kralların elinde/ Tutsak eli öpülesi insanlar ...

Çoktan bizimdir uçan seccade/Başları dara düştü mü hemen/ Yetişiriz öteki kardeşlere.

Oyun ederiz Köse'ye unutmaz kırk yıl/ İyi yürekli çırağı alır hakkını." 


\section{Açık Göndermeler}

"Kitaplarda Gezmek" metninde Adalet Ağaoğlu, Madam Bovary'den, Gönül ki Yetişmekte'den (L' Education Sentimentale) ve Venedik'te Ölüm'den ismen bahsetmekle kalmayıp bu eserlerin özelliklerine açık göndermeler de yapmıştır:

“Hirondelle adlı posta arabasında Emma Bovary’nin yanına oturup Rouen'e yol alışlarımız, katedralin önünden ağır ağır geçişlerimiz..."

"Daha şık, daha iç açıcı yerler mi istiyorsunuz? Hem de coğrafyanın içinde geniş parklar, büyük tarihî yapılar, süslü kadınlar mı olsun? Gönül ki Yetişmekte'nin (L’Education Sentimentale) sayfalarında Flaubert size bol bol sunacaktır bunları. İlk adımda Seine Nehri kıyısından bir vapura binip Nogent surSeine'e doğru yol alabilirsiniz. Bu arada gözlerinizin önünden Saint- Louis Adası, Cité, Notre Dame Kilisesi de bir bir geçecektir. Bir başka gün siz de Frédéric'in peşine takılıp Champs de Mars'da 19. yüzyıl şıkları arasında olabilirsiniz."

“Venedik'te son günüm. Lido'da, Hotel des Bains'in taraçasına bakan çay salonunda, Thomas Mann'ın ailecek çekilmiş fotoğrafı karşısında oturmuş, ötede, kumsalda bir güneşlenme koltuğunda ölüveren, soylu, yaşlı, ünlü Alman yazar Aschenbach'ın daha az önce, hası şapkasıyla Tadzio'nun peşinden deniz kıyısına indiğini düşünüyorum."

"Çocuk Kitaplığında Sabah Tartışması" adlı metinde Mehmet Güler, La Fontaine Masalları, Nasrettin Hoca Fıkraları ve Andersen Masalları gibi eserlerden doğrudan alıntılarla açık gönderme yapmıştır:

La Fontaine'den “Kaplumbağa'nın biri bıkmış, usanmış yaşadığı yerden. Uzak ülkelerin özlemini çekmeye başlamış. Derdini iki ördeğe açmış: ' İstersen seni dünyanın öbür ucuna uçururuz.' demiş ördekler. 'Hem gezer hem bilgini, görgünü artırırsın'. 'Olur.' demiş kaplumbağa. íki ördek bir değnek almışlar ağızlarına: 'Haydi tutun bakalım.' demişler. 'Ama sakın ağzımı açayım deme.' Kaplumbağa söz vermiş konuşmamaya. Ağzıyla tutunmuş değneğe. Uçmaya başlamışlar. Aşağıdan görenler şaşırmış: 'Şuna bakın, kaplumbağa uçuyor.' demişler. Kaplumbağa geveze mi geveze... Bir parça da övüngen. 'Elbette uçuyorum.' der demez, ağzından kaçırmış değneği. Düşüp karpuz gibi kırılıvermiş.”

"Nasrettin Hoca, ters bindiği eşeğini sürüp giderken herkes kahkahalarla gülüyordu. Geriye döndü, kendine gülenlere seslendi: 'Eşeğime ters bindiğim için gülüyorsunuz değil mi?' dedi. 'Evet' diye bağırdılar. 'Onun için gülüyoruz.' dediler. Nasrettin Hoca: 'Bunu otomobil mi sandınız? Üstüne bindiğim bir eşek. Otomobiller gibi dikiz aynası olsa arkamı görürdüm. Olmadığına göre, elbette ki ters bineceğim."” 


\section{Okuma Kültürü Teması Metinlerinin Metinler Arasılık Bakımından İncelenmesi}

“Örneğin 'Kibritçi Kız’ sımsıcak bir masaldır, değil mi? Danimarka'nın karına, buzuna, fırtınasına karşı koyan o küçük kızın kibritlerinin alevi değil, yüreğinin sıcaklığıdır."

"Canım Kitap" metninde Suut Kemal Yetkin, Nurullah Ataç'tan doğrudan alıntı yaparak açık gönderme yapmıştır:

“Nurullah Ataç, ölüm yatağında, kendisini görmeye gelen Sabahattin Teoman’a 'Hastalıkta ağrıları dindirici en iyi ilaç şiirmiş, boyuna şiir okuyorum, dememiş miydi?”"

"Kitap" adlı metinde de metnin yazarı Muzaffer Hacıhasanoğlu, Oktay Akbal'dan doğrudan alıntı yapmıştır: "'Futbol seyircisi kadar kitap okuyucusuna kavuştuğumuz gün, uygarlık savaşını kazanacağız.' diyor Oktay Akbal."

"Sait Faik Adasında" metninde sadece hikâyelerin adı belirtilmemiş, hikâyelerin belirli özellikleri hatırlatılarak açık göndermeler de yapılmıştır:

"Vapuru çığlık çığlığa izleyen martılarda Sait Faik'e ait gizli bir şeyler buluyorum. Onun öykülerindeki 'topal martı' bunların içinde olmalı, diye düşünüyorum."

“Dülger balıkları ölürken Sait Faik'in adını fısıldaşıyorlar." ifadesi ile Dülger Balığı'nın Ölümü hikâyesine gönderme yapılmıştır.

Bizim Köy Bir Balıkçı Köyüdür adlı öyküsünden “Barba Niko'dur şu kırmızı sakallı olan. Şu, yaşlıcası Hristo'dur. Öbürü Karavokiri'dir, İbram'dır, Koço'dur." sözleri alınmıştır.

“Öykünün kahramanı Projektörcü ne hoş adamdı. Sesi yağmurlu havada ıslanmış gibi hep kısık. Gülümseyerek anlatıyor her şeyi. Yüzü gibi kalbi de sıcak, belli."

“Arka sokaklardan birine sapıyoruz. Fazla yürümüyoruz, önümüze kocaman bir kilise çıkıyor. 0 anda Sait Faik'in 'Evimiz kilisenin karşısındaydı' diye başlayan 'Papaz Efendi' adlı öyküsünü anımsıyorum. Başımı kaldırınca kilisenin çan kulesini görüyorum: 'Kilisenin çan kulesi, ön taraftaki boş arsaydı. İki tane çanı vardı. Biri merasimle ölü günlerde çalan büyük çan, öteki her gün dua ve vapur vaktini köye haber veren küçük çan..."

“'Hişt, hişt!..' diye bir ses geliyor kulağıma. Bu sesin doğadan mı, yoksa Sait Faik'in aynı adlı öyküsünden mi geldiğini tam olarak anlayamıyorum. Boş ver, diyorum kendi kendime. 'Gelsin de nereden gelirse gelsin. Bir hişt sesi gelmedi mi fena. Geldikten sonra yaşasın çiçekler, böcekler, insanoğulları..." 


\section{Örtük Göndermeler}

"Kitaplar Gezmek" metninde her ne kadar eserlere atıf yapma yoluyla eserler arası gönderimler yapılmış olsa da söz konusu eserlerle ilgili bazı ayrıntılar örtük gönderme yoluyla da verilmeye çalışıımıştır:

"Seksen günlük dünya turunu bir saat içinde tamamladığımız yıllar" (Kitaplarda Gezmek-Adalet Ağaoğlu) ile Seksen Günde Devr-i Âlem'e gönderme yapılmıştır.

“Robinson’la bir adada geçen ömrümüz..." (Kitaplarda Gezmek-Adalet Ağaoğlu) ile Robinson Cruosoe'ya gönderme yapılmıştır.

“Tabii Sait Faik'le birçok kez Burgazada'ya gittik, Hayırsızada'ya bile çıktık; onun balıkçılarıyla gelin yüzlü bir sinaritin peşine düştük biz de" (Kitaplarda Gezmek-Adalet Ağaoğlu) ifadesiyle ise Sait Faik hikâyelerine gönderme yapılmıştır.

"Çocuk Kitaplığında Sabah Tartışması" metninde kitaplar hem kendi ağızlarından kendilerini tanıtmakta hem de birbirlerini eleştirirken aynı zamanda özelliklerini de belirtmektedirler:

Don Kişot ile ilgili yapılan örtük gönderme "Sen herkesi korkutsan da beni korkutamazsın şövalye dostum. O cılız atınla tahta kılıııın forsu Orta Çağlarda kaldı. Yel değirmenleriyle savaşır gibi davranma bizlere"dir (Çocuk Kitaplığında Sabah Tartışması-Mehmet Güler).

Küçük Prens “Kendi kafana göre iki düş ülkesi yaratmışsın. Birinde Güliver'i devlerle karşılaştırıyorsun, birinde de cücelerle..." sözleriyle Güliver'i eleştirirken Güliver ise kendisini şu sözlerle anlatmaya çalışır: "Her insanın bir dev, bir cüce yanı bulunur. Ben bunu temsil ediyorum" (Çocuk Kitaplığında Sabah Tartışması-Mehmet Güler).

Küçük Prens ise "bu giz, kapalıık sende oldukça hep yalnız kalacaksın çocukların yanında." (Çocuk Kitaplığında Sabah Tartışması-Mehmet Güler) denilerek eleştirilir.

"Keloğlan" şiirinde şair Kırk Haramiler ve Yüz Yıl Uyuyan Güzel masallarına da gönderme yapmıştır:

“Açılıverir tüm kapılar, / Güzel, kurtulur haramiler elinden. ....

Uyandırırız bir ülkeyi yüz yıllık uykusundan."

\section{Tartışma}

Metinler arası ilişkileri sağlayan "yazarlar arası, eserler arası, türler arası, açık ve örtük göndermeler" bakımından incelenen on altı metinden dört tanesinde (Kütüphane, Kitap Saygısı, Rejin Hanım ve İmza Günü) hiçbir metinler arası söyleme rastlanılmamıştır. Geriye kalan on iki metinde ise 


\section{Okuma Kültürü Teması Metinlerinin Metinler Arasılık Bakımından İncelenmesi}

en fazla metinler arası söylem "Kitaplarda Gezmek", "Sait Faik Adasında" ve "Çocuk Kitaplığında Sabah Tartışması" metinlerinde tespit edilmiştir.

Metinlerde özellikle eserler arası göndermeler fazladır. Dolayısıyla bu metinleri okuyan öğrenciler aynı anda gönderme yapılan eserlerle de tanışmış olacaklardır. "Böylece okur bir metnin ilişki kurduğu diğer metinler hakkında bilgi edindiğinde o metni daha rahat yorumlayabilir ve kendi deneyimlerini, yazarın bilgi ve deneyimleriyle birleştirebilir" (Coşkun Ögeyik, 2008: 116).

Metinleri okuyan öğrenciler örtük gönderimleri tespit ederken analiz, değerlendirme gibi üst düzey bilişsel becerileri kullanacaklardır. Nitekim Köksal ve Ünal (2008), çalışmalarında metinlerin, metinler arası okumayla işlendiğinde hem okuduğunu anlamanın hem de bilgi, kavrama, uygulama, analiz, sentez ve değerlendirme basamaklarında anlamanın üst düzeyde gerçekleştiğini belirtmektedirler.

Metinlerde dikkati çeken bir diğer husus ise farklı yazarlar tarafından aynı eserler ve yazarlara göndermeler yapılmasıdır. Platon, Sokrates, Sait Faik, Cervantes gibi yazarlara ve onların eserlerine farklı yazarlar metinlerinde yer vermişlerdir. Bu şekilde öğrenciler okudukları metinlerde yeni yazarlarla da tanışma fırsatı bulacaklardır ve Coşkun Ögeyik'in (2008) belirttiği üzere okuyucular, o metnin metinler arası ilişki kurduğu önceki kaynakları araştırmaya ve o metinlerin söylem özelliklerini bağıntısal olarak ele almaya yöneleceklerdir.

Metinlerde dolaylı ya da doğrudan gönderme yapılan yazarlar ve eserler arasında Platon, Sokrates, Aristoteles, Epiktetos, Herakleitos, Horatius, Ovidius, Vergilius, Seneca, Petrarca, Rabelais, Cervantes, Gothe, Rimboud, Çehov, Evliya Çelebi, Sait Faik, Nurullah Ataç, Oktay Akbal, La Fontaine Masalları, Nasrettin Hoca Fıkraları ve Andersen Masalları örnek verilebilir. İsimlere dikkat edildiğinde genellikle yabancı yazarlara ve eserlerine gönderme yapıldığı dikkat çekmektedir. Ders kitaplarına seçilecek metinlerde yabancı yazarlar kadar Türk edebiyatının yazarlarına da yer verilen örneklerin seçilmesi öğrencilerin Türk edebiyatı yazarları ve eserlerini tanımaları açısından da önemli olabilir.

Illköğretim Türkçe Dersi Öğretim Programı ve Kılavuzu'nda (1-5. Sınıflar) belirtilen metinler arası anlam kurmayı sağlayabilecek öncelikli metinler ders kitaplarıdır. Ayrıca ilköğretim 1-5. sınıflarda hedeflenen temel becerilerin 6-8. sınıflar da kazanılmış olması beklenir. Bu nedenle ders kitapları için metin seçilirken metinler arası anlam kurmayı sağlayabilecek metinlere yer verilmesi gerekmektedir.

Bu araştırmada okuma kültürü temasındaki metinler analiz edilmiştir. Başka araştırmacılar diğer temalarda metinler arası söylemlere yer verilme oranlarını araştırabilirler. 


\section{Kaynakça}

Akbulut, G. (2009). Metinlerarası ilişkiler bağlamında dünün Ferdâ'sından günün Ferdâ'sına bir bakış. Turkish Studies, 4(1-I), 736-759.

Aktulum, K. (2000) Metinlerarası ilişkiler. İstanbul: Öteki Yayınları.

Akyol, H. (2010). Yeni programa uygun Türkçe öğretim yöntemleri. Ankara: Pegem A Yayıncılık.

Allen, G. (2000). Intertextuality. London: Routledge.

Aydın, M. (Editör) (2011). ilköğretim Türkçe ders kitabı 7. Ankara: Koza Yayın Dağıtım.

Bars, M. E. (2013). Kerem ile Aslı hikâyesinde metinlerarası ilişkiler. Uluslararası Sosyal Araştırmalar Dergisi,6 (24), 68-82.

Bayrak Akyıldız, H. (2010). Tanpınar'ın romanlarında metinlerarası ilişkiler. Turkish Studies, 5(3), 715-727.

Coşkun Ögeyik, M. (2008). Metinlerarasılık ve yazın eğitimi. Ankara: Anı Yayıncııı.

Deniz, K. (Editör) (2011). Illköğretim Türkçe ders kitabı 6. Ankara: MEB Devlet Kitapları.

Edmuns, L. (2001). Intertextuality and the reading of roman poetry. London: The Johns Hopkins Univesity Press.

Gökalp Alpaslan, G. G. (2009). Metinlerarası ilişkiler ışı̆̆ında Cemal Süreya şiirinin bileşenleri. Turkish Studies, 4(1I), 436-463.

Günay, D. (2007). Metin bilgisi. İstanbul: Multilingual.

Işıksalan, N. (2007). Postmodern öğreti ve bir postmodern roman çözümlemesi: Kara Kitap/ Orhan Pamuk. Anadolu Üniversitesi Sosyal Bilimler Dergisi, 7(2), 419-466.

Karatay, H. (2010). Türkçe dersi öğretim araçlarında yapılandırmacılık: metinlerarasılık. Mustafa Kemal Üniversitesi Sosyal Bilimler Enstitüsü Dergisi. 7(14), 155-178.

Köksal, K. ve Ünal, E. (2008). Metinler arası okumanın okuduğunu anlamaya etkisi. Elektronik Sosyal Bilimler Dergisi, 7(26), 154-169.

MEB (2006). Ilköğretim Türkçe dersi (6-8. sınıflar) öğretim programı. Ankara: Devlet Kitapları Müdürlüğü Basım Evi.

MEB (2009). Ilköğretim Türkçe dersi (1-5. sınıflar) öğretim programı ve kılavuzu. Ankara: Devlet Kitapları Müdürlüğü Basım Evi.

Özbay, M. (2003). Öğretmen görüşlerine göre Ankara merkez ilköğretim okullarında Türkçe öğretimi. Ankara: Gölge Ofset Matbaacilık.

Plett, H. (Editör) (1991). Intertextuality. Newyork: Walter de Gruyter

Qasımova, L. (2011). Metinlerarası ilişkiler açııından Mustafa Kutlu’nun beşlemesi. A.Ü.Türkiyat Araştırmaları Enstitüsü Dergisi [TAED]. 46, 61-86.

Rızvanoğlu, E. (2007). Söyleşimcilik, metinlerarasılık : Bakhtin, Kristeva, Barthes. Ankara: Hacettepe Üniversitesi Sosyal Bilimler Enstitüsü. Yayınlanmamış Yüksek Lisans Tezi.

Toklu, O. (2009). Dilbilime giriş. Ankara: Akçağ Yayıncılık.

Tunç, G. (2009). "Leylâ ile Mecnun" ve "Ferhad ile Şirin" anlatılarının meşrulaştırma kavramı odağında çağdaş edebiyata metinlerarası yansımaları. Millî Folklor Dergisi, 21 (83), 19-29.

Yıldırım, A. ve Şimşek, H. (2005). Sosyal bilimlerde nitel araştırma yöntemleri. Ankara: Seçkin Yayıncılık. Yıldız, H. H. (Editör) (2010). Illköğretim Türkçe ders kitabı 6. Ankara: Pasifik Yayınları. 